Article

\title{
Pholiota nameko Polysaccharides Promotes Cell Proliferation and Migration and Reduces ROS Content in $\mathrm{H}_{2} \mathrm{O}_{2}$-Induced L929 Cells
}

\author{
Tzu-Jung Sung ${ }^{1,+}$, Yu-Ying Wang ${ }^{1,+}$, Kai-Lun Liu ${ }^{1}$, Chun-Hsu Chou ${ }^{2}$, Ping-Shan Lai ${ }^{3}$ and \\ Chang-Wei Hsieh 1,4,*iD \\ 1 Department of Food Science and Biotechnology, National Chung Hsing University, 145 Xingda Rd., \\ South Dist., Taichung City 402, Taiwan; vi840811@gmail.com (T.-J.S.); sicawang1206@gmail.com (Y.-Y.W.); \\ changeonestune@gmail.com (K.-L.L.) \\ 2 Dr. Jou Biotech Co., Ltd., No.21, Lugong S. 2nd Rd., Lukang Township, Changhua Country 505, \\ Taiwan; dr.jason.jou@gmail.com \\ 3 Department of Chemistry, National Chung Hsing University, 145 Xingda Rd., South Dist., Taichung City 402, \\ Taiwan; pslai@email.nchu.edu.tw \\ 4 Department of Medical Research, China Medical University Hospital, Taichung 404, Taiwan \\ * Correspondence: welson@nchu.edu.tw; Tel.: +886-4-2284-0385 (ext. 5031); Fax: +886-4-2287-6211 \\ + These authors contributed equally to this study and share first authorship.
}

Received: 29 November 2019; Accepted: 9 January 2020; Published: 10 January 2020

\begin{abstract}
Pholiota nameko, a type of edible and medicinal fungus, is currently grown extensively for food and traditional medicine in China and Japan. It possesses various biological activities, such as anti-inflammatory, anti-hyperlipidemia and antitumor activities. However, P. nameko has rarely been discussed in the field of dermatology; identifying its biological activities could be beneficial in development of a new natural ingredient used in wound care. To evaluate its in vitro wound healing activities, the present study assessed the antioxidant and anti-collagenase activities of $P$. nameko polysaccharides (PNPs) prepared through fractional precipitation $(40 \%$, $60 \%$ and $80 \%(v / v))$; the assessments were conducted using reducing power, hydroxyl radical scavenging activity, dichloro-dihydro-fluorescein diacetate and collagenase activity assays. The ability of PNPs to facilitate L929 fibroblast cell proliferation and migration was assessed using 3-(4,5-dimethylthiazol-2-yl)-2,5-diphenyltetrazolium bromide (MTT) and scratch assays. The findings indicated that, among all fractions, PNP- 80 showed the best antioxidant and anti-collagenase activity, as measured by their reducing power ( $\mathrm{IC}_{50}$ of PNP- 80 was $2.43 \pm 0.17 \mathrm{mg} / \mathrm{mL}$ ), the hydroxyl radical scavenging $\left(\mathrm{IC}_{50}\right.$ of $\mathrm{PNP}-80$ was $2.74 \pm 0.11 \mathrm{mg} / \mathrm{mL}$ ) and collagenase activity assay, and significantly reduced cellular ROS content, compared with that of $\mathrm{H}_{2} \mathrm{O}_{2}$-induced L929 cells. Moreover, PNP-80 significantly promoted L929 fibroblast proliferation and migration, compared with the control group. Overall, we suggested that PNP-80 could be a promising candidate for further evaluation of its potential application on wound healing.
\end{abstract}

Keywords: Pholiota nameko; antioxidant; reactive oxygen species; scratch assay; proliferation

\section{Introduction}

Cellular oxidative stress is related to the overproduction of ROS, such as superoxide anions $\left(\mathrm{O}_{2} \bullet^{-}\right)$, hydrogen peroxide $\left(\mathrm{H}_{2} \mathrm{O}_{2}\right)$, and hydroxyl radicals $(\bullet \mathrm{OH})$, and can occur because of exogenous factors as well as endogenous factors, such as aging, diabetes, obesity and vascular disorders [1-6]. These factors give rise to excessive ROS production that leads to oxidative stress, which can negatively affect wound healing, directly and indirectly degrade ECM proteins, weaken dermal fibroblast functions, 
and cause abnormal inflammation, resulting in non-healing wound [7]. Therefore, reducing oxidative stress is crucial for the functioning of fibroblasts during wound healing [8]. The wound-healing process can be aided by antioxidants from natural sources [9]. Furthermore, polysaccharides have been widely indicated they possess great prospect for used in wound healing; for instance, Bletilla striata polysaccharide can promote the proliferation of L929 fibroblasts, scavenge cellular ROS, and downregulate the secretion of pro-inflammatory cytokines [10]. Lentinus edodes polysaccharides could be essential in ameliorating oral ulcers because of their high antioxidant activity [11]. Moreover, moisture balance in the skin is critical to wound healing; dry environments can delay the migration of epidermal cells and slowdown autolysis, and a moist surrounding for the wound can prevent secondary infections [12]. Therefore, natural extracts with antioxidant, anti-inflammatory and moisturizing properties are potential candidates for accelerating wound healing. Pholiota nameko has received increasing attention in recent years because of its nutritive value and unique taste. An increasing number of studies on the bioactivities of $P$. nameko, such as antitumor, antioxidant, and antihyperlipidemic activities, have generated further interest in nameko mushrooms $[13,14]$. Nowadays, there are a lot of studies paying attention to P. nameko extract and polysaccharides for their inflammatory and antioxidant activity; for example, polysaccharides from P. nameko possessed significantly anti-inflammatory activity on egg albumin-induced paw edema in animals [15]. In our previous study, P. nameko polysaccharides (PNPs), namely PNP-40, PNP-60, and PNP-80, were separated through fractional precipitation of ethanol $(40 \%, 60 \%$, and $80 \%(v / v))$, demonstrating that PNPs possessed radical scavenging and $\mathrm{Fe}^{2+}$-chelating activities, and protective effect against $\mathrm{H}_{2} \mathrm{O}_{2}$-induced cellular damage. Moreover, PNPs exhibited 27.61-29.56\% higher moisture retention activity than did glycerol and PNP-80 showed the greatest moisture retention activity of all fractions [16]. These properties mentioned above suggest that PNPs might have potential application for wound healing.

The process of wound healing can be divided into the following phases: inflammatory, proliferative, and remodeling. Several factors could affect the wound-healing process, such as oxidative damage, infection, and venous sufficiency [17]. The migration of fibroblasts to the wound site and their proliferation are particularly essential for wound healing because of their ability to break down the fibrin clot, deposit extracellular matrix (ECM) components and collagen, form granulation tissue and contract the lesion's borders toward the center in the wound area-all important to the wound-healing process [7]. Furthermore, they secrete various signaling molecules that stimulate macrophage activation, such as interferons (INF)- $\alpha, \beta$, and $\gamma$, and facilitate keratinocyte differentiation, proliferation, and migration, such as keratinocyte growth factor [18,19]. Accordingly, facilitating the migration and proliferation of fibroblast could be one of the means of improving wound healing.

In addition, chronic wound healing is characterized by the excessive expression of pro-inflammatory cytokines and proteases, such as collagenase and elastase, released from neutrophils in the inflammatory stage, which disrupt the balance between extracellular matrix (ECM) degradation and deposition [20]. Elevated expression of metalloproteinases (MMPs) might break the balance of the healing process in the inflammatory phase [21]. It has been indicated that the topical application of metalloproteinase inhibitors can improve chronic wound [22,23]. Thereby, natural products with inhibition activity against metalloproteinase might imply that they could improve non-healing wounds.

However, PNPs have rarely been discussed in the field of dermatology and the in vitro wound-healing effects of PNPs have yet to be reported. Therefore, the purpose of the present study was to further evaluate the potential application of PNPs on wound healing.

\section{Materials and Methods}

\subsection{Materials and L929 Cell Line}

P. nameko cultivated in Puli Township, Nantou County, Taiwan (R.O.C.) was purchased from the Rich Year Farm in Nantou, Taiwan. The mouse fibroblast cell line L929 (ATCC ${ }^{\circledR}$ CCL-1 ${ }^{\mathrm{TM}}$ ) sourced from ATCC (Manassas, VA, USA) was cultured in Dulbecco's modified Eagle's medium 
(DMEM, Gibco ${ }^{\circledR}$, Grand Island, NY, USA) containing $10 \%$ fetal bovine serum (FBS, Gibco ${ }^{\circledR}$, Grand Island, NY, USA) and antibiotics (100 U penicillin and $100 \mathrm{U} / \mathrm{mL}$ streptomycin, Gibco ${ }^{\circledR}$, Grand Island, NY, USA) under $5 \% \mathrm{CO}_{2}$ at $37{ }^{\circ} \mathrm{C}$. Cells were harvested after reaching confluence by using $0.05 \%$ trypsin-EDTA (Gibco ${ }^{\circledR}$, Grand Island, NY, USA). Fresh culture medium was added to produce single-cell suspensions for further incubation. Potassium ferricyanide $\left(\mathrm{C}_{6} \mathrm{~N}_{6} \mathrm{FeK}_{3}\right)$ and ferric chloride $\left(\mathrm{FeCl}_{3}\right)$ were purchased from Showa Chemical Industry Co., Ltd., Tokyo, Japan. Trichloroacetic acid was purchased from Alfa Aesar, Tewksbury, MA, USA. Sodium salicylate, ferrous sulfate heptahydrate $\left(\mathrm{FeSO}_{4}\right)$, hydrogen peroxide $\left(\mathrm{H}_{2} \mathrm{O}_{2}\right)$, the fluorescein-labeled dye $2^{\prime}, 7^{\prime}$-dichlorofluorescein diacetate (DCF-DA), 3-(4,5-dimethylthiazol-2-yl)-2,5-diphenyltetrazolium bromide (MTT), and ascorbic acid (vitamin C) were purchased from Sigma-Aldrich, St. Louis, MO, USA. Collagenase from Clostridium hislolyticum (Type I, 0.25-1.0 units/mg, Sigma, St. Louis, MO, USA) was purchased from Sigma-Aldrich, USA. All other chemicals used were of analytical grade.

\subsection{Extraction and Fractionation}

PNPs were prepared as described in our previous study [16]. PNPs were extracted using ethanol precipitation. Ethanol was added at final concentrations of $40 \%, 60 \%$, and $80 \%$, and the resulting PNPs were named PNP-40, PNP-60, and PNP-80, respectively. The three different ethanol precipitations of PNP samples were extracted, lyophilized, and refrigerated at $4{ }^{\circ} \mathrm{C}$.

\subsection{Reducing Power Assay}

The reducing power assay was performed as previously described but with modification [24]. Equal volumes $(312.5 \mu \mathrm{L})$ of PNPs dissolved in $\mathrm{ddH}_{2} \mathrm{O}(0.3125-5.000 \mathrm{mg} / \mathrm{mL})$, phosphate buffer $(0.2 \mathrm{M}$, $\mathrm{pH}$ 6.6), and $1 \%$ potassium ferricyanide were mixed. The mixture was heated to $50{ }^{\circ} \mathrm{C}$ for $20 \mathrm{~min}$; subsequently, $312.5 \mu \mathrm{L}$ of $10 \%$ trichloroacetic acid was added to the mixture, followed by $312.5 \mu \mathrm{L}$ of distilled water and $62.5 \mu \mathrm{L}$ of $0.1 \%$ ferric chloride. Absorbance was immediately detected at $700 \mathrm{~nm}$. Vitamin C (0.0063-0.1014 mg/mL) was used as the positive control. The $\mathrm{IC}_{50}$ value was equal to the concentration of samples producing 0.5 absorbance at $700 \mathrm{~nm}$.

\subsection{Hydroxyl Radical Scavenging Activity}

Hydroxyl radical scavenging activity was assessed using a previously described Fenton reaction, with modification [25]. Briefly, $50 \mu \mathrm{L}$ of PNPs dissolved in $\mathrm{ddH}_{2} \mathrm{O}(0.3125-5.000 \mathrm{mg} / \mathrm{mL})$ was incubated with $50 \mu \mathrm{L}$ of sodium salicylate $(9 \mathrm{mM}), 50 \mu \mathrm{L}$ of $\mathrm{FeSO}_{4}(9 \mathrm{mM})$, and $50 \mu \mathrm{L}$ of $\mathrm{H}_{2} \mathrm{O}_{2}(0.025 \%$, w/v) at $37^{\circ} \mathrm{C}$ for $30 \mathrm{~min}$. Absorbance was then determined at $510 \mathrm{~nm}$. Deionized water was used as the blank control, and vitamin C $(0.3125-5.000 \mathrm{mg} / \mathrm{mL})$ was served as the positive control. Hydroxyl radical scavenging activity was calculated using the following equation:

\section{Hydroxyl radical scavenging activity $(\%)=$ (absorbance of blank control -} absorbance of sample/absorbance of blank control) $\times 100 \%$

$\mathrm{IC}_{50}$ of PNPs was derived from the formula, $\mathrm{Y}=100 \times \mathrm{A} 1 /(\mathrm{A} 1+\mathrm{X})$, using GraphPad Prism 6.01 and $Y$ denotes the relative content of hydroxyl radical $(Y=100$ when $X=0)$, A1 denotes $I_{50}$ of PNPs and $\mathrm{X}$ denotes the concentration of PNPs [26].

\subsection{Measurement of Inhibitory Effect on Collagenase}

Inhibitory effect on collagenase was performed by modified Wang's method [27]. To measure the collagenase activity, $100 \mu \mathrm{L}$ of 200 units/mL collagenase and $100 \mu \mathrm{L}$ PNPs $(5000,2500,1250 \mu \mathrm{g} / \mathrm{mL})$ were mixed together and incubated at $37^{\circ} \mathrm{C}$ for $15 \mathrm{~min}$, weighed at $1 \mathrm{mg}$ of azo dye-impregnated collagen substrate and mixed with $800 \mu \mathrm{L} 0.1 \mathrm{M}$ Tris- $\mathrm{HCl}$ buffer ( $\mathrm{pH} 7.0$ ), then added together at $43^{\circ} \mathrm{C}$ for $1 \mathrm{~h}$ under shaking conditions. Subsequently, the reaction mixture was centrifuged at $3000 \mathrm{rpm}$ for $10 \mathrm{~min}$, 
and the absorbance was read at $520 \mathrm{~nm}$ using the ELISA reader. Distilled water was used as control, and $100 \mu \mathrm{L}$ of epigallocatechin gallate (EGCG, 5000, 2500, $1250 \mu \mathrm{g} / \mathrm{mL}$ ) was used as positive control.

The inhibitory rate of collagenase $(\%)=\left(A_{c}-A_{t s} / A_{c}\right) \times 100 \%$

where $A_{c}$ represents the absorbance of the control, and $A_{t s}$ represents the absorbance of the test sample.

\subsection{ROS Generation}

The ROS generation assay was performed using a previously described method, with modification [28]. Specifically, the concentration of ROS was evaluated using a DCF-DA probe (Sigma Aldrich). The L929 cells were seeded in 24-well plates at a concentration of $1.5 \times 10^{4}$ cells/well and allowed to adhere for $24 \mathrm{~h}$. The cells were pre-incubated with PNPs $(500 \mu \mathrm{g} / \mathrm{mL})$ for $24 \mathrm{~h}$ and then exposed to $\mathrm{H}_{2} \mathrm{O}_{2}(0.75 \mathrm{mmol} / \mathrm{L})$ for an additional $2 \mathrm{~h}$ after adhesion. After treatment, the L929 cells were incubated in DMEM, without FBS, containing DCF-DA $(10 \mu \mathrm{M})$ at $37{ }^{\circ} \mathrm{C}$ in the dark for $30 \mathrm{~min}$. After removal of the probe by washing twice in phosphate-buffered saline (PBS), the final results were evaluated using fluorescence microscopy (Olympus IX51, Tokyo, Japan). Images were captured, and the mean density values were analyzed using Image J software.

\subsection{Cell Proliferation}

Cell proliferation was determined through the MTT assay by using a previously described procedure, with modification [29]. Briefly, L926 cells were seeded in three 96-well plates (1800 cells/well). After $24 \mathrm{~h}$ (day 0), the PNPs $(500 \mu \mathrm{g} / \mathrm{mL})$ dissolved in DMED medium were added and then incubated for $0 \mathrm{~h}, 24 \mathrm{~h}$ and $48 \mathrm{~h}$ at $37^{\circ} \mathrm{C}$ with $5 \% \mathrm{CO}_{2}$ in a humidified atmosphere, followed by $100 \mu \mathrm{L}$ of MTT, and the plate was incubated for $2 \mathrm{~h}$. Absorbance was measured at a test wavelength of $570 \mathrm{~nm}$ to evaluate cell proliferation. Absorbance was measured on days 0, 1, and 2.

\subsection{Scratch Assay}

The scratch assay-typically used to evaluate the wound-healing capacity of a substance or molecule-was performed using a previously described method, with modification [30]. The assay was used to study cell migration and proliferation, which are crucial for tissue repair. L929 cells were seeded $\left(10^{5}\right.$ cells $\left./ \mathrm{mL}\right)$ in a 24 -well plate and cultured for $24 \mathrm{~h}$. Cell culture monolayers were scratched with a sterile $200-\mu \mathrm{L}$ pipette tip across the center of the well. After scratching, the wells were gently washed twice with PBS to remove the detached cells. The cells were then treated with $500 \mu \mathrm{g} / \mathrm{mL} \mathrm{of}$ the three different PNPs prepared in DMED medium. Control cells were not treated with any PNP. Wound-healing efficiency was monitored at 0 and $24 \mathrm{~h}$. The scratch closure rate is expressed as the percentage of scratch closure on an initial area basis, according to the following Equation:

$$
\text { Scratch closure rate }=\left(A_{t 0}-A_{t} / A_{t 0}\right) \times 100
$$

where $A_{t 0}$ is the scratch area at time $0 \mathrm{~h}$ and $A_{t}$ is the corresponding scratch area at $24 \mathrm{~h}$. The values shown are the means of three wells from three independent experiments.

\subsection{Microscopy and Image Analysis}

Scratch wound closure was examined using an inverted microscope, and images were captured and analyzed using fluorescence microscopy (Olympus IX51) software. The scratch closure area was monitored at different time intervals $(0$ and $24 \mathrm{~h})$ to calculate wound closure [31].

\subsection{Statistical Analysis}

All data are expressed as means \pm standard deviations. Statistical data processing was implemented through dispersion analysis using SPSS 20 software. Statistical analysis was performed using one-way 
ANOVA and Duncan's multiple range tests, and a $p$ value of $<0.05$ was considered to indicate statistical significance.

\section{Results and Discussion}

\subsection{Reducing Power and Hydroxyl Radical Scavenging Activity}

It was indicated that the antioxidant activities of natural compounds are associated with their wound-healing properties [9]. Therefore, to evaluate the antioxidant activity of PNPs, we used two different antioxidant assays, the reducing power and hydroxyl radical scavenging activity, to simulate the environmental oxidative stress in non-healing wound. Hydroxyl radicals overproduced via uncontrolled Fenton reaction disturb healing process in delayed wound healing [32]. The reducing power can be used to assess to extent to which a compound reduces $\mathrm{Fe}^{3+}$ to $\mathrm{Fe}^{2+}$, and the higher absorbance value at $700 \mathrm{~nm}$ is, the stronger is antioxidant [33]. The reducing power levels derived from PNPs and vitamin $C$ increased in a dose-dependent manner in Figure 1. PNP-80 $\left(\mathrm{IC}_{50}=2.43 \pm 0.17 \mathrm{mg} / \mathrm{mL}\right)$ had a higher reducing power for ferric ion than did PNP-40 and PNP-60 $(p$ $<0.05)$. The growth rates of PNP-40 and PNP- 60 were slow, with the absorbance values being 0.43 and 0.31 at $5.0 \mathrm{mg} / \mathrm{mL}$, respectively.

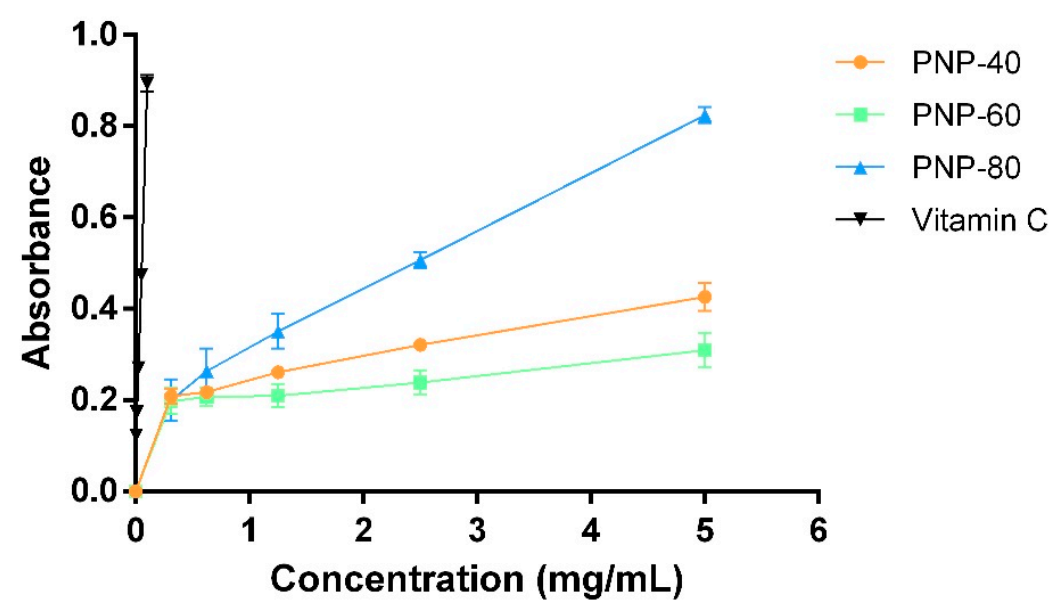

Figure 1. Reducing power of PNPs and vitamin $C$ at different concentrations. The experiments were conducted in triplicate independently $(n=3)$, and the data are expressed as the means \pm standard error (SE).

Hydroxyl radicals are among the most reactive and hazardous free radicals. Overproduction hydroxyl radical overwhelms oxidation-reduction system and causes damage in cellular protein, DNA, lipid and wound-healing related cells, fibroblast, arising delayed healing of wounds [9]. Therefore, to evaluate the hydroxyl radical scavenging activity of the PNPs in vitro, we used the Fenton reaction system as a model. The hydroxyl radical scavenging activities of the PNPs and vitamin C are illustrated in Figure 2. All samples exhibited hydroxyl radical scavenging activity in a dose-dependent manner. The IC F0 $_{50}$ value of PNP-80 and PNP-60 was $2.74 \pm 0.11 \mathrm{mg} / \mathrm{mL}$ (95\% confidence intervals $=2.520$ to $2.965 \mathrm{mg} / \mathrm{mL}$ and $\left.\mathrm{R}^{2}=0.9406\right)$ and $4.25 \pm 0.09 \mathrm{mg} / \mathrm{mL}(95 \%$ confidence intervals $=4.069$ to $4.436 \mathrm{mg} / \mathrm{mL}$ and $\mathrm{R}^{2}=0.9816$ ), respectively; additionally, at $5 \mathrm{mg} / \mathrm{mL}$, the scavenging abilities of PNP-80, PNP-60, PNP-40, and vitamin C were $60.17 \%, 51.44 \%, 47.25 \%$, and $94.29 \%$, respectively. These results indicate that PNP- 80 exhibited greater potency to donate hydrogen to hydroxyl radicals than did the other fractions $(p<0.05)$ [34]. 


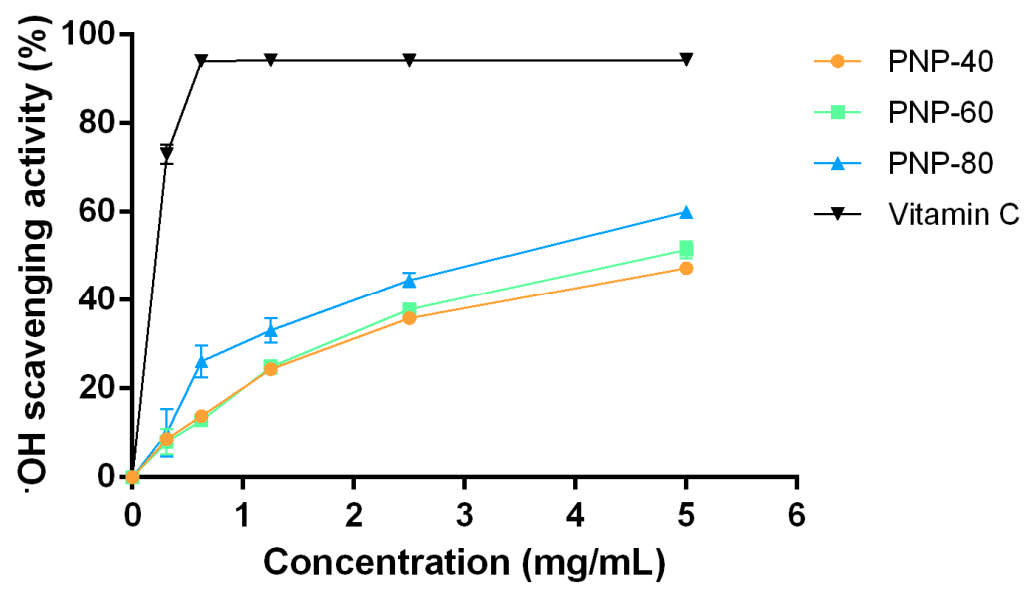

Figure 2. Hydroxyl radical scavenging activity of PNPs and vitamin C. The experiments were conducted in triplicate independently $(n=3)$, and the data are expressed as the means \pm standard error (SE).

Low-molecular-weight polysaccharides have a less compact structure than do high-molecular-weight polysaccharides. This signifies that low-molecular-weight polysaccharides have more free functional groups, such as carboxyl, amino, and hydroxyl groups which could react with free radicals and then stabilize them, than do high-molecular-weight polysaccharides [35]. The antioxidant properties of chitosan weighing 2.2-300.0 $\mathrm{kDa}$ are inversely related to their molecular weights [36], explaining why PNP-80 (4.40 kDa) exhibited a more pronounced scavenging activity (measured through its reducing power and hydroxyl radical scavenging activity) than did PNP-60 $(21.57 \mathrm{kDa})$ and PNP-40 (333.49 $\mathrm{kDa})$ at a concentration of $5 \mathrm{mg} / \mathrm{mL}$. In terms of reducing power, the absorbance value at $700 \mathrm{~nm}$ of G. lucidum polysaccharides- 80 was 0.138 at a concentration of $2.0 \mathrm{mg} / \mathrm{mL}$ [37], suggesting that PNP-80 could be more effective electron donors that can react with free radicals and convert them into more stable products. In terms of hydroxyl radical scavenging activity, the $\mathrm{IC}_{50}$ value of Auricularia auricular polysaccharides that was reported to be greater than $5.0 \mathrm{mg} / \mathrm{mL}$ is similar to that of PNPs [38]. Our results show that among the three fractions, PNP-80 had the greatest antioxidant activity. Moreover, although PNPs did not exhibit antioxidant activity as good as vitamin C did, PNPs possess a variety of wound healing-related functions, such as moisturizing [16] which vitamin did not hold.

\subsection{Anti-Collagenase Activity of PNPs}

Collagenase is one of matrix metalloproteinases (MMPs) capable of breaking down the extracellular matrix $(\mathrm{ECM})$, the major components of connective tissue, which can support the skin structure, maintain skin elasticity and play an important role in wound healing [39]. However, it has been shown that overexpression of collagenase was associated with chronic wound and treatment chronic wound with metalloproteinase inhibitor could improve delayed healing wound [22,23]. To evaluate if PNPs have the inhibitory ability against collagenase, we used in vitro collagenase activity assay as an evaluation model. Epigallocatechin gallate (EGCG), the predominant catechin in tea, possesses the inhibition of collagenolytic activity by collagenase and is usually used as positive control in collagenase activity assay [40-42]. The collagenase inhibitory activity of PNPs and epigallocatechin gallate (EGCG) was shown in Figure 3. All of samples inhibited collagenase in a dose-dependent manner at a range of concentration from 125 to $500 \mu \mathrm{g} / \mathrm{mL}$. The inhibitory activity of PNP-40, PNP-60 and PNP-80 ranged from $25 \%$ to $33 \%$, from $26 \%$ to $39 \%$ and from $32 \%$ to $61 \%$ at $125-500 \mu \mathrm{g} / \mathrm{mL}$, respectively. The inhibitory activity of PNP-80 at a concentration of $500 \mu \mathrm{g} / \mathrm{mL}$ was significantly higher than that of PNP-60, PNP-40 and EGCG. Although the collagenase inhibitory activity of all samples did not show significant differences at a concentration of $125 \mu \mathrm{g} / \mathrm{mL}$ and $250 \mu \mathrm{g} / \mathrm{mL}$, the inhibitory activity of PNP-80 was slightly higher than that of PNP-40, PNP-60, and EGCG. The result indicated that PNPs might improve delayed healing wound by reducing the collagenase activity. 


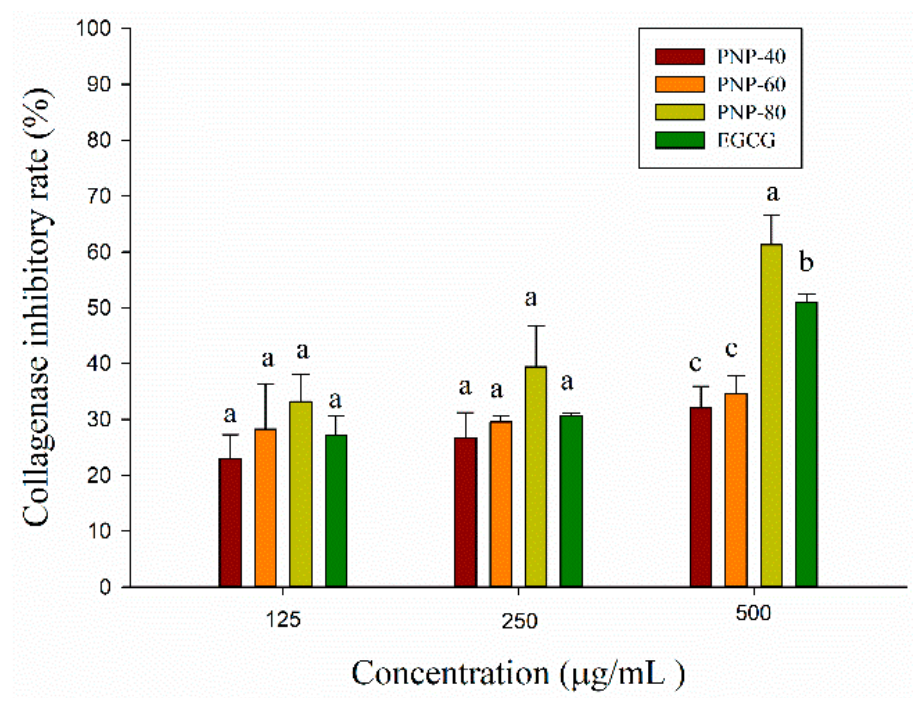

Figure 3. Anti-collagenase activity of PNPs $(125,250,500 \mu \mathrm{g} / \mathrm{mL})$ and EGCG $(125,250,500 \mu \mathrm{g} / \mathrm{mL})$. The experiments were conducted in triplicate independently $(n=3)$, and the data are expressed as the means \pm standard error (SE). ${ }^{\text {a-c }}$ Means within the same concentration followed by the same letter were not significantly different $(p>0.05)$.

Collagenases are a group of zinc-containing proteinases, which contains $\mathrm{Zn}$ ion at its active site that facilitates interaction with an inhibitor [43]. Previous studies showed that PNPs have the ability to chelate metal [16], which might suggest that the inhibitory mechanism of PNPs against collagenase is due to their ability to chelate $\mathrm{Zn}$ ion at collagenase's active site and hamper the interaction between the substrate and its active site.

\subsection{Effect of Intracellular ROS Generation}

Wound healing is a dynamic and precisely controlled process and can be divided into three phases: inflammatory, proliferative and remodeling phase. During the inflammatory phase, neutrophils infiltrate to the wound area in order to combat microbes and clear cell debris via secreting $\mathrm{H}_{2} \mathrm{O}_{2}$ and proteases. Even though these substances have a beneficial effect on the wound healing process, overproduction $\mathrm{H}_{2} \mathrm{O}_{2}$ gives rise to the non-healing wound via weakening wound-healing related cell, fibroblast $[17,44]$. In our previous study, we proved that pre-treated with PNPs reduced the $\mathrm{H}_{2} \mathrm{O}_{2}$-induced damage to L929 cell using MTT assay, suggesting PNPs might protect L929 cell from programmed cell death by ameliorating oxidative stress in L929 cell [16]. To assess if PNPs possess the ability against $\mathrm{H}_{2} \mathrm{O}_{2}$-induced oxidative stress, we utilized ROS generation assay as a model. We had already proved that PNPs did not exhibit cytotoxicity toward L929 cells under a concentration of $500 \mu \mathrm{g} / \mathrm{mL}$ [16]. The levels of ROS, determined through DCFH-DA staining, produced in control cells, $\mathrm{H}_{2} \mathrm{O}_{2}$-induced cells without PNPs pretreatment and with PNPs pretreatment $(500 \mu \mathrm{g} / \mathrm{mL})$ are shown in Figure 4a; in this figure, green fluorescence indicates ROS production. This study observed a notable increase in ROS production in the $\mathrm{H}_{2} \mathrm{O}_{2}$-induced cells without PNPs, however, the ROS levels were lower in the PNPs-pretreated groups. ROS production was also quantified using image J software (Figure $4 \mathrm{~b}$ ). Compared with the $\mathrm{H}_{2} \mathrm{O}_{2}$-induced L929 cells without PNPs pre-treatment, the $\mathrm{H}_{2} \mathrm{O}_{2}$-induced L929 cells pre-treated with PNPs had significantly reduced ROS levels. The relative fluorescence intensity of $\mathrm{H}_{2} \mathrm{O}_{2}$-induced L929 cells without PNPs was $0.15, \mathrm{H}_{2} \mathrm{O}_{2}$-induced L929 cells pre-treated with PNP-80, PNP-60 and PNP-40 which were reduced to 0.06, 0.10, and 0.09, respectively. Overall, PNP-80 showed the greatest free-radical scavenging activity and reduced the level of ROS in the $\mathrm{H}_{2} \mathrm{O}_{2}$-treated cells by $53.33 \%$. Moreover, it was indicated P. nameko polysaccharides have the potential to increase the activity of cellular antioxidant enzymes, such as superoxide dismutase (SOD), thereby reducing cellular ROS contents [45], suggesting PNP-40, PNP-60 and PNP-80 might also ameliorate cellular oxidative stress via up-regulating SOD expression. According to these results, 
we infer that PNPs could attenuate $\mathrm{H}_{2} \mathrm{O}_{2}$-induced damage via improving cellular oxidative stress. These results are similar to that of sulfated polysaccharides isolated from the edible marine algae Padina tetrastromatica which weaken $\mathrm{H}_{2} \mathrm{O}_{2}$-induced cellular damage via the reduction of intracellular reactive oxygen species level [46].
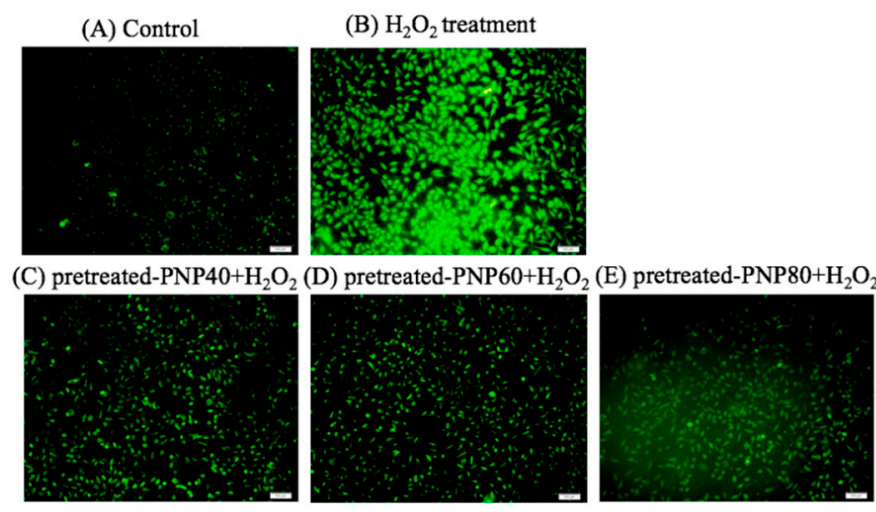

(a)

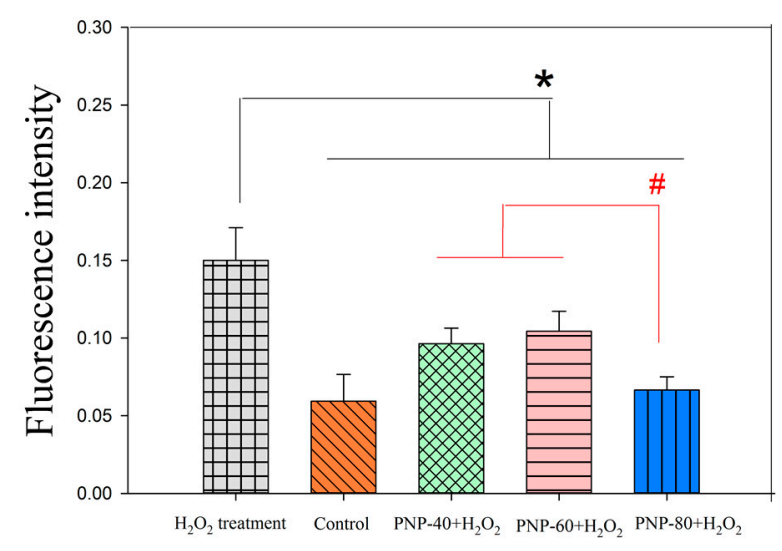

(b)

Figure 4. (a) Radical scavenging activity of PNPs $(500 \mu \mathrm{g} / \mathrm{mL})$ on $\mathrm{L} 929$ cells against $\mathrm{H}_{2} \mathrm{O}_{2}$-induced ROS generation (scale bar $=100 \mu \mathrm{m}$ ). Control (A), $\mathrm{H}_{2} \mathrm{O}_{2}$-induced L929 cells without PNPs pre-treatment (B), with PNP-40 pre-treatment (C), with PNP-60 pre-treatment (D), and with PNP-80 pre-treatment (E). (b) Quantitative analysis of the radical scavenging effect of PNPs-pretreated on L929 cells against $\mathrm{H}_{2} \mathrm{O}_{2}$-induced ROS generation. The experiments were conducted in triplicate independently $(n=3)$, and the data are expressed as the means \pm standard error (SE) $\left({ }^{*} p<0.05\right.$ compared with $\mathrm{H}_{2} \mathrm{O}_{2}$-treated L929 cells without PNPs; \# $p<0.05$ compared with PNPs-pretreated against $\mathrm{H}_{2} \mathrm{O}_{2}$-induced L929 cells).

\subsection{Cell Proliferation and Migration}

Proliferation and recruitment of fibroblasts in the wound area are particularly important to wound healing process because fibroblasts are directly liable for depositing ECM, forming granulation tissues and contracting wound lesions. Consequently, substances that could enhance the proliferation and migration activity of fibroblast implies they have the potential to accelerate the wound healing process [47].

In wound healing, a major concern is the positive response of fibroblasts toward the materials of interest; L929 is widely used for testing if the samples possess the stimulation activity by studying its cell proliferation activity [48,49]. The MTT assay was used to determine the proliferation of L929 fibroblast cells. Proliferative activity can be determined by measuring the reduction of yellow tetrazolium salt to purple formazan crystals, which indicates cells' metabolic state [50]. The relative fold changes in cell proliferation are shown in Figure 5. The proliferative activity of L929 cells treated with PNP-80 
increased significantly compared with that of the control cells on day 1 . However, on day 2, all three PNPs significantly promoted the proliferative activity of L929 cells compared with that of the control cells $(p<0.05)$. The proliferative activity of L929 cells treated with PNP-80, PNP-60, and PNP-40 exhibited 5.80-, 5.29-, and 5.16-fold changes on day 2 compared with the changes observed on day 0 , respectively, which were significantly higher than those in the control cells. These results indicate that in L929 cells, PNPs greatly promote proliferation, which is crucial in skin wound healing.

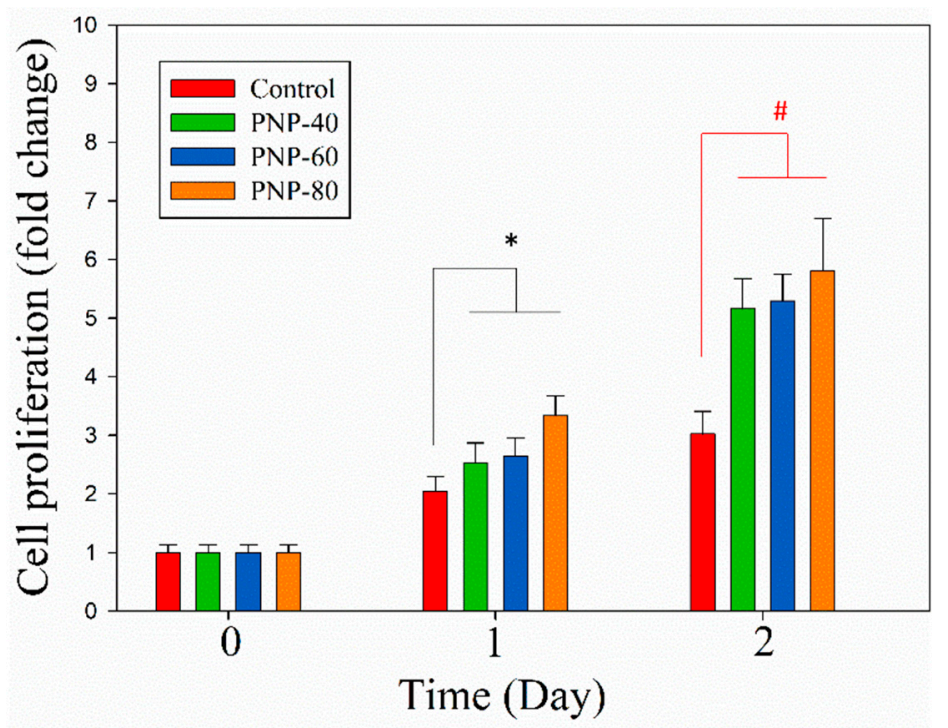

Figure 5. Proliferation of L929 cells treated with PNPs $(500 \mu \mathrm{g} / \mathrm{mL})$ for 0,1 , and 2 days (relative to day $0)$. The experiments were conducted in triplicate independently $(n=3)$, and the data are expressed as the means \pm standard error (SE) $\left({ }^{*} p<0.05\right.$ compared with control cells on day 1 ; $\# p<0.05$ compared with control cells on day 2 ).

We next determined whether PNPs affect L929 cell migration. Cellular migration is an essential process in wound and cutaneous repair, and fibroblasts can traverse tissue environments to degrade, repair, and remodel the ECM [51]. We used the in vitro scratch assay to measure the migration of L929 cells into a cell-free gap in the tissue culture dish. As presented in Figure 6a,b, during the time from 0 to $24 \mathrm{~h}$, PNPs significantly increased the closure speed in the cells relative to the control cells $(11.83 \%)$. L929 cells that were treated with PNPs showed a significant increase in closure rate, with the rates being $35.82 \%$ (PNP-40), 34.81\% (PNP-60), and 54.75\% (PNP-80). The closure rates of L929 cells treated with PNPs at $24 \mathrm{~h}$ were higher than those of the control cells by $194.25-362.80 \%$. The increased migratory activity of L929 cells treated with PNPs suggests that PNPs have the potential to enhance cutaneous repair $[47,52]$.

In human skin fibroblasts, 24-h exposure to ammonium-chitosan conjugates was reported to result in a significantly increased closure rate (approximately 70\%) compared with the rate observed in control cells (approximately 45\%) [53]. Sargassum ilicifolium aqueous extracts were also reported to engender an enhanced wound closure rate (97.83\%) in L929 cells at $24 \mathrm{~h}$ compared with the rate observed in control cells (46.11\%); hence, the wound closure rate of the treated cells was higher than that of the control cells by $112.17 \%$ [31], indicating PNPs demonstrated better enhancement in fibroblast migration. 


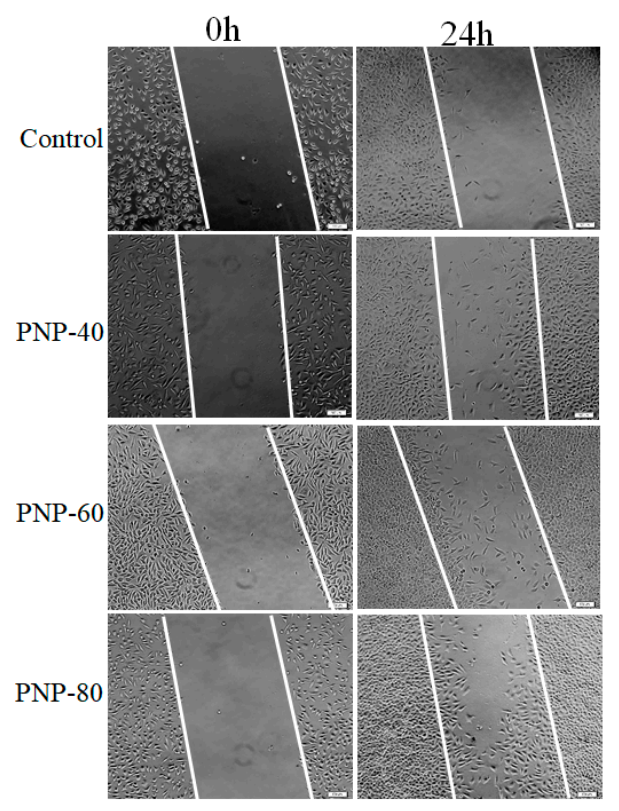

(a)

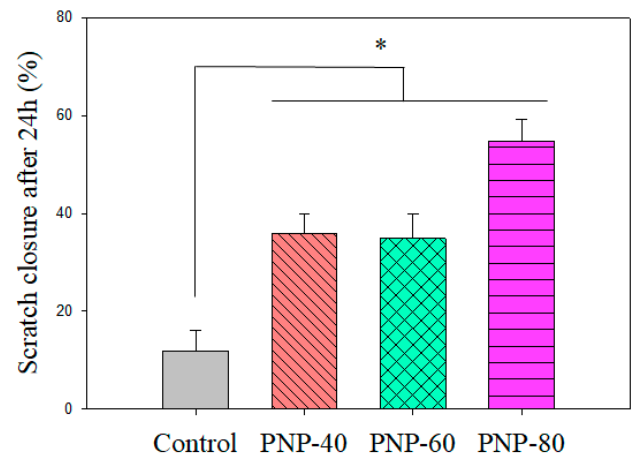

(b)

Figure 6. (a) L929 fibroblast cells treated PNPs (500 $\mu \mathrm{g} / \mathrm{mL})$ and control group observed after injury to the cell monolayer by using an in vitro scratch assay immediately after scratching $(0 \mathrm{~h})$ and $24 \mathrm{~h}$ after scratching (scale bar $=100 \mu \mathrm{m}$ ). (b) Quantitative analysis of L929 fibroblast cell scratch closure $24 \mathrm{~h}$ after the scratch assay. The experiments were conducted in triplicate independently $(n=3)$, and the data are expressed as the means \pm standard error (SE) $\left({ }^{*} p<0.05\right.$ compared with control cells; \# $p<0.05$ compared with PNP-treated cells).

It was indicated that $\beta$-glucans are a multi-functional modulator of wound healing [54], for instance, $(1 \rightarrow 3)-(1 \rightarrow 6)-\beta$-D-glucan from Aureobasidium pullulans stimulates dermal fibroblast proliferation and migration [55]. Moreover, our previous study showed that the $\beta$-D-glucan contents in PNP-40, PNP-60 and PNP-80 were 20.20\%, 12.20\% and 10.15\%, respectively [16], and other report was indicated as a $\beta$-D-glucan- $(1 \rightarrow 3)$-linked, substituted at $O-6$ by $\beta$-D-Glcp or $(1 \rightarrow 6)$-linked $\beta$-D-Glcp side chains using NMR and methylation analyses [56], suggesting that $\beta$-d-glucan might be one of active substances in PNPs elevating cell migration and proliferation.

A moist wound environment has a variety of beneficial effects on wound healing process, such as prevention of tissue dehydration and cell death, accelerated angiogenesis, increased breakdown of dead tissue and fibrin, compared with a dry wound environment [57]. Our previous study showed the moisture-retention rate of PNP-80 was $64.17 \%$ after $96 \mathrm{~h}$ exposed to $10 \%$ relative humidity $(\mathrm{RH})$ and it was higher than that of PNP-40 (63.42\%) and PNP-60 (63.21\%) and far higher than that of glycerol 
(49.53\%) [16]. In this study, we found that PNP-80 exhibited the best reducing power and hydroxyl radical scavenging activity of all fractions, greatly reduced ROS content in $\mathrm{H}_{2} \mathrm{O}_{2}$-induced $\mathrm{L} 929$ cells and significantly enhanced the proliferation and migration rate of L929 cells, compared with control group, suggesting that PNP-80 might be a promising candidate for further evaluation of its potential application on wound healing. In addition, we did further assess if PNPs have the antibacterial activity against Escherichia coli and Staphylococcus aureus (the data was not shown here). Although the result indicated that PNPs did not exhibit antibacterial activity against E. coli and S. aureus in agar well diffusion assay at a concentration of $10 \mathrm{mg} / \mathrm{mL}$, it does not mean PNPs are not appropriate to be used as functional ingredients in wound healing related agents. That is because the flaw might be made up by adding additional antibacterial agents.

Furthermore, identifying and refining the active compounds in PNPs using gel filtration chromatography and ion-exchange liquid chromatography is important and necessary because PNPs did not show great potency in in vitro wound healing assay.

\section{Conclusions}

In our study, PNPs extracted using fractional precipitation show great antioxidant activity in vitro; additionally, they significantly reduce ROS production, promote proliferation, and increase the wound closure rate at the cellular level. These attributes provide information for the first time on the effectiveness of PNPs in enhancing in vitro wound healing. The findings indicate that PNP-80 shows the greatest antioxidant, anti-collagenase, proliferative, and migratory activities among the fractions. PNP-80 was the most promising candidate of all fractions for further evaluation of its potential application on wound healing. Further investigations into the effects of PNPs on wound healing must be conducted on an animal model and their stability; moreover, the structure and mechanisms underlying the wound-healing effects of PNPs warrant investigation.

Author Contributions: Conceptualization, T.-J.S., Y.-Y.W.; methodology, T.-J.S., Y.-Y.W.; software, T.-J.S.; validation, T.-J.S., Y.-Y.W. and C.-H.C.; formal analysis, Y.-Y.W.; investigation, T.-J.S., Y.-Y.W.; resources, C.-H.C.; data curation, K.-L.L.; writing — original draft preparation, T.-J.S.; writing—review and editing, K.-L.L.; visualization, K.-L.L.; supervision, P.-S.L., C.-W.H.; project administration, P.-S.L., C.-W.H.; funding acquisition, C.-W.H. All authors have read and agreed to the published version of the manuscript.

Funding: This work was funded by the Ministry of Science and Technology, Republic of China (Grant No. MOST 106-2622-B-005-012-CC2 and MOST 108-2622-B-005-003-CC2). This research was partially funded by the Jou Biotech Corp.

Conflicts of Interest: The authors declare no conflict of interest. The funders had no role in the design of the study; in the collection, analyses, or interpretation of data; in the writing of the manuscript, or in the decision to publish the results.

\section{References}

1. D'Orazio, J.; Jarrett, S.; Amaro-Ortiz, A.; Scott, T. UV radiation and the skin. Int. J. Mol. Sci. 2013, 14, 12222-12248. [CrossRef]

2. Junqueira, V.B.; Barros, S.B.; Chan, S.S.; Rodrigues, L.; Giavarotti, L.; Abud, R.L.; Deucher, G.P. Aging and oxidative stress. Mol. Asp. Med. 2004, 25, 5-16. [CrossRef]

3. Madamanchi, N.R.; Vendrov, A.; Runge, M.S. Oxidative stress and vascular disease. Arterioscler. Thromb. Vasc. Biol. 2005, 25, 29-38. [CrossRef]

4. Maritim, A.; Sanders, A.; Watkins, J., III. Diabetes, oxidative stress, and antioxidants: A review. J. Biochem. Mol. Toxicol. 2003, 17, 24-38. [CrossRef]

5. Martin, P.; Nunan, R. Cellular and molecular mechanisms of repair in acute and chronic wound healing. Br. J. Dermatol. 2015, 173, 370-378. [CrossRef] [PubMed]

6. Savini, I.; Catani, M.V.; Evangelista, D.; Gasperi, V.; Avigliano, L. Obesity-associated oxidative stress: Strategies finalized to improve redox state. Int. J. Mol. Sci. 2013, 14, 10497-10538. [CrossRef] [PubMed]

7. Gonzalez, A.C.d.O.; Costa, T.F.; Andrade, Z.D.A.; Medrado, A.R.A.P. Wound healing-A literature review. An. Bras. Dermatol. 2016, 91, 614-620. [CrossRef] [PubMed] 
8. Dunnill, C.; Patton, T.; Brennan, J.; Barrett, J.; Dryden, M.; Cooke, J.; Leaper, D.; Georgopoulos, N.T. Reactive oxygen species (ROS) and wound healing: The functional role of ROS and emerging ROS-modulating technologies for augmentation of the healing process. Int. Wound J. 2017, 14, 89-96. [CrossRef] [PubMed]

9. Süntar, I.; Akkol, E.K.; Nahar, L.; Sarker, S.D. Wound healing and antioxidant properties: Do they coexist in plants? Free Radic. Antioxid. 2012, 2, 1-7. [CrossRef]

10. Chen, Z.; Cheng, L.; He, Y.; Wei, X. Extraction, characterization, utilization as wound dressing and drug delivery of Bletilla striata polysaccharide: A review. Int. J. Biol. Macromol. 2018, 120, 2076-2085. [CrossRef]

11. Yu, Z.; LiHua, Y.; Qian, Y.; Yan, L. Effect of Lentinus edodes polysaccharide on oxidative stress, immunity activity and oral ulceration of rats stimulated by phenol. Carbohydr. Polym. 2009, 75, 115-118. [CrossRef]

12. Weller, C.; Team, V. Interactive dressings and their role in moist wound management. In Advanced Textiles for Wound Care; Elsevier: Amsterdam, The Netherlands, 2019; pp. 105-134.

13. Zhang, Y.; Liu, Z.; Ng, T.B.; Chen, Z.; Qiao, W.; Liu, F. Purification and characterization of a novel antitumor protein with antioxidant and deoxyribonuclease activity from edible mushroom Pholiota nameko. Biochimie 2014, 99, 28-37. [CrossRef] [PubMed]

14. Zheng, L.; Zhai, G.; Zhang, J.; Wang, L.; Ma, Z.; Jia, M.; Jia, L. Antihyperlipidemic and hepatoprotective activities of mycelia zinc polysaccharide from Pholiota nameko SW-02. Int. J. Biol. Macromol. 2014, 70, 523-529. [CrossRef] [PubMed]

15. Li, H.; Lu, X.; Zhang, S.; Lu, M.; Liu, H.J.B. Anti-inflammatory activity of polysaccharide from Pholiota nameko. Biochemistry 2008, 73, 669. [CrossRef]

16. Chou, C.-H.; Sung, T.-J.; Hu, Y.-N.; Lu, H.-Y.; Yang, L.-C.; Cheng, K.-C.; Lai, P.-S.; Hsieh, C.-W. Chemical analysis, moisture-preserving, and antioxidant activities of polysaccharides from Pholiota nameko by fractional precipitation. Int. J. Biol. Macromol. 2019, 131, 1021-1031. [CrossRef]

17. Guo, S.a.; DiPietro, L.A. Factors affecting wound healing. J. Dent. Res. 2010, 89, 219-229. [CrossRef]

18. Stunova, A.; Vistejnova, L. Dermal fibroblasts-A heterogeneous population with regulatory function in wound healing. Cytokine Growth Factor Rev. 2018, 39, 137-150. [CrossRef]

19. Tracy, L.E.; Minasian, R.A.; Caterson, E. Extracellular matrix and dermal fibroblast function in the healing wound. Adv. Wound Care 2016, 5, 119-136. [CrossRef]

20. McCarty, S.M.; Percival, S.L. Proteases and delayed wound healing. Adv. Wound Care 2013, 2, 438-447. [CrossRef]

21. Lazaro, J.; Izzo, V.; Meaume, S.; Davies, A.; Lobmann, R.; Uccioli, L. Elevated levels of matrix metalloproteinases and chronic wound healing: An updated review of clinical evidence. J. Wound Care 2016, 25, 277-287. [CrossRef]

22. Chin, G.A.; Thigpin, T.G.; Perrin, K.J.; Moldawer, L.L.; Schultz, G.S. Treatment of chronic ulcers in diabetic patients with a topical metalloproteinase inhibitor, doxycycline. Wounds 2003, 15, 315-323.

23. Lobmann, R.; Schultz, G.; Lehnert, H. Proteases and the diabetic foot syndrome: Mechanisms and therapeutic implications. Diabetes Care 2005, 28, 461-471. [CrossRef] [PubMed]

24. Gao, J.; Zhang, T.; Jin, Z.-Y.; Xu, X.-M.; Wang, J.-H.; Zha, X.-Q.; Chen, H.-Q. Structural characterisation, physicochemical properties and antioxidant activity of polysaccharide from Lilium lancifolium Thunb. Food Chem. 2015, 169, 430-438. [CrossRef] [PubMed]

25. Zhang, C.-H.; Yu, Y.; Liang, Y.-Z.; Chen, X.-Q. Purification, partial characterization and antioxidant activity of polysaccharides from Glycyrrhiza uralensis. Int. J. Biol. Macromol. 2015, 79, 681-686. [CrossRef]

26. Hazra, B.; Biswas, S.; Mandal, N. Antioxidant and free radical scavenging activity of Spondias pinnata. BMC Complement. Altern. Med. 2008, 8, 63. [CrossRef]

27. Wang, L.; Lee, W.; Oh, J.; Cui, Y.; Ryu, B.; Jeon, Y.-J. Protective effect of sulfated polysaccharides from celluclast-assisted extract of Hizikia fusiforme against ultraviolet B-Induced skin damage by regulating NF- $\mathrm{BB}$, AP-1, and MAPKs signaling pathways in vitro in human dermal fibroblasts. Mar. Drugs 2018, 16, 239. [CrossRef]

28. Hu, Y.-N.; Sung, T.-J.; Chou, C.-H.; Liu, K.-L.; Hsieh, L.-P.; Hsieh, C.-W. Characterization and Antioxidant Activities of Yellow Strain Flammulina velutipes (Jinhua Mushroom) Polysaccharides and Their Effects on ROS Content in L929 Cell. Antioxidants 2019, 8, 298. [CrossRef]

29. Lee, G.Y.; Park, K.G.; Namgoong, S.; Han, S.K.; Jeong, S.H.; Dhong, E.S.; Kim, W.K. Effects of Panax ginseng extract on human dermal fibroblast proliferation and collagen synthesis. Int. Wound J. 2016, 13, 42-46. [CrossRef] 
30. Sudsai, T.; Wattanapiromsakul, C.; Tewtrakul, S. Wound healing property of isolated compounds from Boesenbergia kingii rhizomes. J. Ethnopharmacol. 2016, 184, 42-48. [CrossRef]

31. Premarathna, A.D.; Ranahewa, T.; Wijesekera, S.; Wijesundara, R.; Jayasooriya, A.P.; Wijewardana, V.; Rajapakse, R. Wound healing properties of aqueous extracts of Sargassum illicifolium: An in vitro assay. Wound Med. 2019, 24, 1-7. [CrossRef]

32. Wright, J.A.; Richards, T.; Srai, S.K. The role of iron in the skin and cutaneous wound healing. Front. Pharmacol. 2014, 5, 156. [CrossRef] [PubMed]

33. Benzie, I.F.; Szeto, Y. Total antioxidant capacity of teas by the ferric reducing/antioxidant power assay. J. Agric. Food Chem. 1999, 47, 633-636. [CrossRef] [PubMed]

34. He, J.-Z.; Ru, Q.-M.; Dong, D.-D.; Sun, P.-L. Chemical characteristics and antioxidant properties of crude water soluble polysaccharides from four common edible mushrooms. Molecules 2012, 17, 4373-4387. [CrossRef] [PubMed]

35. Xing, R.; Liu, S.; Guo, Z.; Yu, H.; Wang, P.; Li, C.; Li, Z.; Li, P. Relevance of molecular weight of chitosan and its derivatives and their antioxidant activities in vitro. Bioorg. Med. Chem. 2005, 13, 1573-1577. [CrossRef]

36. Chang, S.-H.; Wu, C.-H.; Tsai, G.-J. Effects of chitosan molecular weight on its antioxidant and antimutagenic properties. Carbohydr. Polym. 2018, 181, 1026-1032. [CrossRef]

37. Kan, Y.; Chen, T.; Wu, Y.; Wu, J. Antioxidant activity of polysaccharide extracted from Ganoderma lucidum using response surface methodology. Int. J. Biol. Macromol. 2015, 72, 151-157. [CrossRef]

38. Xu, S.; Zhang, Y.; Jiang, K. Antioxidant activity in vitro and in vivo of the polysaccharides from different varieties of Auricularia auricula. Food Funct. 2016, 7, 3868-3879. [CrossRef]

39. Ou, M.-C.; Liu, Y.-H.; Sun, Y.-W.; Chan, C.-F. The composition, antioxidant and antibacterial activities of cold-pressed and distilled essential oils of Citrus paradisi and Citrus grandis (L.) Osbeck. Evid.-Based Complement. Altern. Med. 2015, 2015, 804091. [CrossRef]

40. Im, K.H.; Baek, S.A.; Choi, J.; Lee, T.S. Antioxidant, Anti-Melanogenic and Anti-Wrinkle Effects of Phellinus vaninii. Mycobiology 2019, 47, 494-505. [CrossRef]

41. Madhan, B.; Krishnamoorthy, G.; Rao, J.R.; Nair, B.U. Role of green tea polyphenols in the inhibition of collagenolytic activity by collagenase. Int. J. Biol. Macromol. 2007, 41, 16-22. [CrossRef]

42. Shirzad, M.; Hamedi, J.; Motevaseli, E.; Modarressi, M.H. Anti-elastase and anti-collagenase potential of Lactobacilli exopolysaccharides on human fibroblast. Artif. Cells Nanomed. Biotechnol. 2018, 46, 1051-1061. [CrossRef]

43. Pientaweeratch, S.; Panapisal, V.; Tansirikongkol, A.J.P.b. Antioxidant, anti-collagenase and anti-elastase activities of Phyllanthus emblica, Manilkara zapota and silymarin: An in vitro comparative study for anti-aging applications. Pharm. Biol. 2016, 54, 1865-1872. [CrossRef]

44. Wenk, J.; Sabiwalsky, A.; Dissemond, J.; Meewes, C.; Brenneisen, P.; Wlaschek, M.; Scharffetter-Kochanek, K.; Foitzik, A.; Achterberg, V.; Reitz, A. Selective pick-up of increased iron by deferoxamine-coupled cellulose abrogates the iron-driven induction of matrix-degrading metalloproteinase 1 and lipid peroxidation in human dermal fibroblasts in vitro: A new dressing concept. J. Investig. Dermatol. 2001, 116, 833-839. [CrossRef]

45. Islam, T.; Ganesan, K.; Xu, B. New Insight into Mycochemical Profiles and Antioxidant Potential of Edible and Medicinal Mushrooms: A Review. Int. J. Med. Mushrooms 2019, 21, 237-251. [CrossRef]

46. Jose, G.M.; Raghavankutty, M.; Kurup, G.M. Attenuation of hydrogenperoxide-induced oxidative damages in L929 fibroblast cells by sulfated polysaccharides isolated from the edible marine algae Padina tetrastromatica. J. Bioact. Compat. Polym. 2019, 34, 150-162. [CrossRef]

47. Yahaya, E.S.; Cordier, W.; Steenkamp, P.; Steenkamp, V. Effect of ethnomedicinal extracts used for wound healing on cellular migration and intracellular reactive oxygen species release in SC-1 fibroblasts. S. Afr. J. Bot. 2018, 118, 11-17. [CrossRef]

48. Wongpanit, P.; Sanchavanakit, N.; Pavasant, P.; Supaphol, P.; Tokura, S.; Rujiravanit, R. Preparation and Characterization of Microwave-treated Carboxymethyl Chitin and Carboxymethyl Chitosan Films for Potential Use in Wound Care Application. Macromol. Biosci. 2005, 5, 1001-1012. [CrossRef]

49. Lopes, V.R.; Schmidtke, M.; Fernandes, M.H.; Martins, R.; Vasconcelos, V. Cytotoxicity in L929 fibroblasts and inhibition of herpes simplex virus type 1 Kupka by estuarine cyanobacteria extracts. Toxicol. In Vitro 2011, 25, 944-950. [CrossRef] 
50. Hu, X.; Wang, Y.; Zhang, L.; Xu, M. Design of a novel polysaccharide-based cryogel using triallyl cyanurate as crosslinker for cell adhesion and proliferation. Int. J. Biol. Macromol. 2019, 126, 221-228. [CrossRef]

51. Tschumperlin, D.J. Fibroblasts and the ground they walk on. Physiology 2013, 28, 380-390. [CrossRef]

52. Muniandy, K.; Gothai, S.; Tan, W.S.; Kumar, S.S.; Mohd Esa, N.; Chandramohan, G.; Al-Numair, K.S.; Arulselvan, P. In Vitro wound healing potential of stem extract of Alternanthera sessilis. Evid.-Based Complement. Altern. Med. 2018, 2018, 3142073-3142086. [CrossRef]

53. Felice, F.; Zambito, Y.; Belardinelli, E.; Fabiano, A.; Santoni, T.; Di Stefano, R. Effect of different chitosan derivatives on in vitro scratch wound assay: A comparative study. Int. J. Biol. Macromol. 2015, 76, 236-241. [CrossRef]

54. Majtan, J.; Jesenak, M. $\beta$-Glucans: Multi-functional modulator of wound healing. Molecules 2018, $23,806$. [CrossRef]

55. Choi, J.-S.; Kim, J.W.; Jung, G.-W.; Moon, S.-B.; Cho, H.-R.; Sung, S.H.; Jung, J.J.; Kwon, Y.S.; Ku, S.K.; Sohn, J.-H. Effect of a $\beta$-glucan from Aureobasidium on TGF- $\beta$ 1-modulated in vitro dermal wound repair. Toxicol. Environ. Health Sci. 2016, 8, 12-18. [CrossRef]

56. Sovrani, V.; De Jesus, L.I.; Simas-Tosin, F.F.; Smiderle, F.R.; Iacomini, M. Structural characterization and rheological properties of a gel-like $\beta$-D-glucan from Pholiota nameko. Carbohydr. Polym. 2017, 169, 1-8. [CrossRef]

57. Field, C.K.; Kerstein, M.D. Overview of wound healing in a moist environment. Am. J. Surg. 1994, 167, S2-S6. [CrossRef]

(C) 2020 by the authors. Licensee MDPI, Basel, Switzerland. This article is an open access article distributed under the terms and conditions of the Creative Commons Attribution (CC BY) license (http://creativecommons.org/licenses/by/4.0/). 